\title{
THE EFFECTS OF AUTHENTIC PEDAGOGICAL PRACTICES ON STUDENTS' EDUCATIONAL PERFORMANCES AND RETENTION POWER
}

\author{
Sajjad Hussain ${ }^{*}$ \\ Nasir Ahmad $^{* *}$ \\ Farooq Nawaz Khan ${ }^{* * *}$
}

\begin{abstract}
In-practice traditional lecture, discussion and assignments based pedagogical practices play its role in students' learning and retention power. The current study intends to investigate whether authentic pedagogical practices are more effective in terms of enhancing students' educational performances and retention power or the traditional pedagogical practices. Therefore, this study focused on investigating the effects of authentic and traditional pedagogical practices on students' educational performances and retention power at secondary level. The objective was to measure the effects of authentic and traditional pedagogical practices on students' educational performances and retention power. A pre-test post-test comparative group design was adopted to conduct the study. The students of experimental group were exposed to authentic pedagogical practices while the control group was treated on traditional routine pedagogical practices. Data from the experimental and control group were collected through a self-developed test. Thrice was the test administered to both groups, the collected data were analyzed through Mean, Standard Deviation and independent sample t-test. Results of the study concludes that students of experimental group performed higher on the post-test than the students of control group, the performance of experimental group was also better as
\end{abstract}

\footnotetext{
* Lecturer, Center for Education \& Staff Training, University of Swat, Khyber Pakhtunkhwa (KPK), Pakistan

** Assistant Professor, Center for Education \& Staff Training, University of Swat, KPK, Pakistan

A** Assistant Professor and Director, Center for Education \& Staff Training, University of Swat, KPK, Pakistan
} 
compared to the control group on the test of retention power. Keeping in view the results that data yielded, it was recommended that teachers at secondary level may follow authentic pedagogical practices as compared to other traditional ones. Based on the findings of the study relevant and applicable recommendations were made.

Keywords: Authentic Pedagogical Practices, Students' Educational Performance, Retention Power

\section{Introduction}

The introduction of constructivist movement laid the foundation of authentic pedagogies. It was John Dewey, who advocated and introduced the real life experiences in teaching learning process. His favored method of teaching was inquiry-based learning approach which aims to make the students competent in the subject and independent in learning. The education with off campus, practical life importance was the base of Dewey's philosophy. All school practices concentrates on students' intellectual, social, and critical skills development, which enables them to prepare for playing various future roles (Dennis, 2005; Gewirtz, 2009). It was a paradigm shift that changed the pedagogical practices from being students centered to promoting learning through problemsolving approach. Therefore, due to the shift in pedagogical practices teachers became responsible for the facilitation of students learning and for the development of a conducive and sustainable educational environment where students' hidden potentialities could be explored and developed (Baeten, Kyndt, Struyven, \& Dochy, 2010).

According to the State Department report on Education "A Nation at Risk” 2001 public school's practices were found contrary to educational, social and future demands of the state. The report also reflected that American nation is not ready to adopt their selves to the rapidly changing world. Huge investment in the reformation of education, establishment of schools and colleges, changes in the curriculum and other efforts were made to improve the situation, but still today after finishing secondary school most of the students neither want to go to college nor to work. No child lefts behind, standard-based education and like these other programs were initiated but the results were disappointing (Given, 2013). 
Fred M. Newmann a professor of curriculum and instruction in the Wisconsin United States of America came up with a solution to the situation in the form of authentic pedagogy. Head vocates that improvement in the physical structure of schools, changes in the curriculum and other such activities are not as effective as improvement in the pedagogical practices at the school level. In 1995 in an article Authentic Pedagogy: Standards that Boost Students' Performance published in "Issues in restructuring schools" presented authentic pedagogical practices aimed at active learning through problem solving skills, construction of meaning in close relation to real-life situation (Newmann, Marks, \& Gamoran, 1995). Before this, in 1993 along with Wehlage, they devised five standards for authentic pedagogical practices.These standards provide base for improving teachers' classroom instruction and students' authentic achievement. According toNewmann, Marks, and Gamoran (1995) authentic intellectual achievement requires' construction to reach beyond retrieval and imitation of knowledge previously received by the self and others. Authentic construction of knowledge involves application, manipulation, interpretation or analysis of previous knowledge to solve a problem that cannot be solved simply by routine retrieval or reproduction.

Authentic pedagogy is an attempt to convert learner attitude from receiver to generator, constructor and experiential learner. Initially it was defined by Newmann (2007) as instruction aimed at promoting authentic students achievement, while students' authentic achievement means intellectual accomplishments which is more productive and aimed at practical life experiences instead of just information and retrieval. The philosophy of authentic pedagogy is that students should be prepared for the intellectual work which is the demands of their future social roles "intellectual accomplishments that are worthwhile, significant and meaningful” (Newmann, 2007).

Rationale and theoretical framework of the study; traditional pedagogical practices concentrate on teaching the course contents in a way where students' conceptual understanding is ignored. Passive learning through lecture method, notes and imitative style is the most common approach of teachers. Though students attain A and A+ grade in examination but they are unable to qualify an entry test where application of their acquired knowledge is required.

Similarly students' performances on high stake-tests show their inability to solve complex problems and use higher level intellectual skills. Studies conducted on school infrastructure, institutional learning 
environment, socio-economic status of students, family background, curriculum studies, medium of instruction recommended the need for improvement in these areas for the enhancement of students' educational performances. Efforts have been made from time to time by curriculum experts to introduce changes for the better results in 2001, 2006 and 2012 in Pakistan. Similarly efforts for the improvement of infrastructure in the educational institutions have also been made through the financial powers delivery to schools by introducing Parent Teacher Council (PTC old name PTA) in 1999 (Hussain \& Naz, 2013). Educational awareness campaigns have been initiated and from time to time while medium of instruction according to the local and international requirement have been solved to a great extent but the improvement in the performance of students is negligible besides all these efforts. This study, therefore, intend to investigate the input of teacher authentic pedagogical practices in classroom for the improvement of students learning outcomes. Fred Newmann authentic instruction framework was adopted as a theoretical framework for the study.

This study targeted the following sub-areas of the topic in detail;

1. To investigate the effects of authentic pedagogical practices on the educational performances of students

2. To measure the effects of traditional pedagogical practices on the educational performances of students

3. To measure the differences between the educational performances of students on authentic and traditional pedagogical practices

4. To measure the effects of authentic pedagogical practices on students' retention power

5. To measure the effects of traditional pedagogical practices on students' retention power

6. To measure the differences between students' retention power on authentic and traditional pedagogical practices

\section{Literature Review}

Studies in pedagogical practices identified different loopholes affecting students' academic performances. All modern such as; flip learning, cooperative learning, problem solving and traditional such as; lecturing, questioning, tutoring and demonstrating pedagogical approaches concentrate on the improvement of learning process and 
enhancement of students' academic achievement. Authentic pedagogical approach is also the one which focus to boost students learning outcomes (Hussain, Ahmad, Saeed, \& Khan, 2015).

The authenticity of pedagogy can be measured on the following five components defined by the proponent of authentic pedagogy Fred M. Newmann; these standards are;

i. To construct knowledge based on previous learning

ii. To adopt disciplined inquiry in learning

iii. Learning those knowledge/skills/attitude which has value beyond school level

iv. Connecting students' learning with life experiences, and

v. The inclusion of all students in the learning process (Huang, 2014).

The first three components of authentic pedagogies are interrelated and provide foundation to one another. Construction of knowledge is the aim of authentic pedagogy through practical activities which are organized in a way that students with the help of their previous knowledge could construct new knowledge and new meanings from their own perspectives. This process includes synthesizing, evaluating and interpreting information aimed at the construction of new knowledge which includes higher level thinking. It is important to be understood that students need to know what to learn? And is limited to specific time framework and also stay to perform different tasks for the said purpose (Watagodakumbura, 2013; Huang, 2014).

Disciplined-inquiry is the second component of authentic pedagogy. It is an organized and systematic approach of collecting data through scientific method, in-depth study of the collected data and communication of the conclusions made from the inquiry, it leads the learner towards self-regulated learning. The practice of inquiry method enhanced their experiential knowledge of students and helped them to construct their own meanings and explain a specific phenomenon from their own perspective and according to their own understanding. Experiential learning is the gateway of success in the world of work (Dennis, 2005).

Third component is the value of learned knowledge beyond the school level. Dewey was of the view that school is not separate from society but actually it is the part of society where the young generation is prepared in the light of societal expectations. All the learning experiences must be in accordance with the social values. It is necessary that school learning may not be restricted in use to school boundaries but 
it should be valued beyond the school premises (Dennis, 2005). School training is always future directed aimed at the preparation of young generation to their respective future roles. Experiential learning, selfregulated learning and learning by doing are the concepts which reject the theoretical nature of education and stimulate for practical and handson approaches in education. These practical approaches have more value beyond the school boundaries.

Connecting school experiences with life experiences is the fourth component of authentic pedagogy. It concentrates on the connection of school experiences in social life of the students. Learning materials are structure in accordance to social norms, values and practices. Social expectations and demands are inculcated through exemplifying and coloring the instructional materials in classroom learning. The last component is the inclusion of all students in instructional process (Newmann, 2007). Classroom environment is developing in such a manner where each student is provided the opportunity to give input and active participation in the class discussion. Involving all students ensures the learning of all students and that is why it is distinctive than other traditional pedagogical practices (Bartle, 2012).

The authenticity of pedagogy can be strictly judged with the standards provided by different researchers and particularly by the proponent of authentic pedagogy Fred M. Newmann. According to Newmann, Marks, and Gamoran (1995) there are two broader areas of authentic pedagogy;

i. Task assessment which is further subdivided into seven standards

a. Organization of information

b. Specification of alternates

c. Disciplinary content

d. Process

e. Written communication skills

f. The connection of under-study problem to the world and

g. Its value beyond the school/educational institutions

ii. Instruction at classroom which contains four standards that is

a. Higher order thinking

b. Academic conversation among the students and teachers,

c. In-depth knowledge of concept and

d. The activities that connects the world beyond the classroom (Dennis \& O’hair, 2010) 
Students' academic performance in term of marks is not a reliable proof of their overall intelligence. Such students in high stake-tests like engineering and medical, most of the times come up with very poor performance. Therefore, their readiness for practical life is highly doubtful (Harm, 2013; Maddox, 2014). Our examination system reflects only recalling of students' knowledge which is the lowest level of cognitive domain. In the $21^{\text {st }}$ century with full competition in almost all fields of life the learners need more preparation than it was required in previous times. There is frequent need of critical thinking, independent learning, learner empowerment, inquiry-based learning and actual understanding of concepts for its application in practical life instead of rote memorization and studying for the sake of examinations. Societal pressures on education system to meet social demands are increasing day by day as people want to prepare their children for their future roles.

\section{Methodology}

\section{Research Design}

The study was experimental in nature. There are different experimental designs which are used in different experimental contexts according to the needs of the study. True experimental designs are powerful as it controls external and internal threats of the experiment up to a great extent, therefore, in true experimental designs; pre-test posttest comparative group design was adopted for the study as this design meets the requirements of the study.

The students of the both groups were pre-tested with a test to measure their educational performances. After the pre-test, students of experimental group were taught through authentic pedagogical practices, while control group was left to be taught through normal routine traditional pedagogical practices and no extra treatment was given. The study was delimited to the subject of English and total duration of the treatment was four weeks.

\section{Participants}

There were two section of grade 9th in government high school, in section (A) there were thirty two students while in section (B) there were twenty eight students. To equate both sections two students from section 
(A) were transferred to section (B).Section (A) was taken as a control and section (B) as an experimental group of the study.

\section{Instrument and Treatment}

An objective type test was used to measure the performances of the students. A test was developed from $9^{\text {th }}$ grade English textbook. The test was designed to measure the lower and higher level cognitive abilities of students. There were forty (40) Multiple Choice Questions, reflecting different situations.

The test was based on paragraphs which were followed by questions like, the identification of tense used, dictionary and contextual meanings of the underlined words, synonyms and antonyms of bold words and re-arranging sentences, these questions were placed under lower level cognition, whereas, selecting suitable headings for a paragraph, conclusions, use of words in blanks according to the demands of the context presented in the paragraphs and one line summary was asked from the respondents to measure their higher level cognitions.

Some items of the test were taken from Ahmad (2011) $\mathrm{PhD}$ dissertation. Students responses on lower level cognitive items were scored in (correct $=1$, incorrect $=0$ ) while higher level cognitive items were scored with the help of a rubric representing students' performances ( 1 = low level, 2 = average, 3 = above than average and 4 = good).

To measure the retention power of students, students of experimental and control groups were post-post-tested after a time of one month of post-test of the study. Same test was administered to the respondents and data were collected and analyzed to measure students' retention differences that exist in students because of traditional routine and authentic pedagogical practices. The significant of the results were analyzed statistically.

Twelve (12) lesson plans were prepared and delivered to the experimental group. Students were engaged in the learning process through extensive reading materials, audios, sound recording and playback, group games for hands-on practice, and short writing tasks. Besides these, everyday life videos of English native people were supplemented to motivate students to speak English in their everyday life. Custom-designed videos for pronunciation, semantics and comprehension were utilized to motivate students for self-directed learning. 
The session time was divided into three phases,

i. Introduction to lesson done was carried out by students, identifying the objectives of lesson which was followed with the dissemination of reading materials.

ii. Reading of reading materials, identifying words need to be explain and preparing questions or topic for group discussion. Sometimes this phase was limited to structure the problems in the lesson and students were put together into different groups to work on the selected structured problems collectively.

iii. The third phase was further divided into two portions (a) discussion/summary presentation/answers of questions (b) reflection of the whole session and the distribution of next session topic.

Both groups' students were assessed for three times, first before the experiment, second after the experiment and third after one month of the second post-test. Pre and post-tests of the groups were to measure the differences between the performance of student in control and experimental groups while the third time test was to measure the retention power of the students in traditional and authentic pedagogical practices.

\section{Reliability and Validity}

The test was developed in accordance to students' mental level and was pilot tested with 10 students of Government High School Muhabatabad Mardan. The reliability co-efficient of the instrument was calculated using Kuder Richardson (KR 21) it was .692 which is acceptable (Iacobucci \& Adam, 2003), while the validity of the instrument was assured through comparing of the test items and contents from table of specification. It was also checked by three subject specialists who identified some minor changes keeping in view the grammatical nature of the test items.

\section{Data Analysis}

The collected data were placed in SPSS version 20 and was analyzed through independent sample t-test. The differences between the performances of control and experimental groups' students were 
measured through independent sample t-test. Results along with interpretations are as under;

\section{Results}

Results of the study are as under;

Table 1

Students Performances on pre-test (Lower level Cognitive domain)

\begin{tabular}{lccccc}
\hline \multicolumn{1}{c}{ Study Groups } & Mean S & Std & $\begin{array}{c}\text { Mean } \\
\text { difference }\end{array}$ & $\begin{array}{c}t \\
\text { value }\end{array}$ & $p$ \\
\hline $\begin{array}{l}\text { Experimental Group } \\
\text { Control Group }\end{array}$ & 32.06 & 4.191 & .5000 & .474 & .639 \\
\hline
\end{tabular}

Table 1 shows the performances of control and experimental group students. The mean scores of experimental and control groups did not have significant difference. The mean score of experimental group is 32.06 and that of the control group 32.56, the mean difference was .50. The $t$ value 1.659 which was not significant as the $p$ value is .639 which is higher than .05. These scores reflect the lower level cognitive questions in the test. The low difference shows the same level performance of both the groups' students. Students of control and experiment groups were found similar in their educational performances. The performances of both control and experimental group students were similar which reflects nearly equal performances on the lower level cognitive knowledge. It was assumed that students' performances would not be different as both the groups were taught by the same teacher and the contents of the text was also same which was confirmed from the results.

Table 2

Students Performances on pre-test (Higher level Cognitive domain)

\begin{tabular}{lcclcc}
\hline \multicolumn{1}{c}{ Study Groups } & Mean & Std & $\begin{array}{c}\text { Mean } \\
\text { difference }\end{array}$ & $\begin{array}{c}t \\
\text { value }\end{array}$ & $p$ \\
\hline Experimental Group & 15.78 & 2.74 & .3000 & .136 & \multirow{2}{*}{.892} \\
Control Group & 15.48 & 2.86 & .300 & & \\
\hline
\end{tabular}

Table 2 illustrates the performances of students at higher level cognitive questions in the test. The mean scores of experimental and control groups are slightly different and this difference is .300. The mean score of experimental group was 15.78 and the mean score of control 
group is 15.48. The $t$ valuewas.136 which was not significant as the $p$ value .892 is higher than .05. Students of experimental and control group were equal in higher intellectual ability level questions.

Students of both groups attempted the questions of higher level cognitive domain in the test. The difference between experimental and control is not significant. The responses of control and experimental groups were scattered from the mean scores as can be seen in Standard Deviation. It was concluded that there is no significant difference between students of control and experimental group students in higher level thinking.

Table 3

Students Performances on Post-test (Lower level Cognitive domain)

\begin{tabular}{lccccc}
\hline \multicolumn{1}{c}{ Study Groups } & $\begin{array}{c}\text { Mean } \\
\text { S }\end{array}$ & Std & $\begin{array}{c}\text { Mean } \\
\text { difference }\end{array}$ & $\begin{array}{c}t \\
\text { value }\end{array}$ & $p$ \\
\hline $\begin{array}{l}\text { Experimental Group } \\
\text { Control Group }\end{array}$ & 37.94 & 5.084 & 5.880 & 7.791 & .000 \\
\hline
\end{tabular}

Table 3 shows the performances of students at lower level knowledge on post-test. The mean scores of experimental and control groups have significant differences. The mean score of experimental group was 37.94 and of the control group it was 32.06, the mean difference was 5.880 . The t value 9.791 which was highly significant as the $\mathrm{p}$ value .000 is less than .05 . As a whole, students of experimental group perform higher on lower intellectual ability question.

Students' performance after the experiment on post-test has been improved. This improvement is the evidence of the effectiveness of authentic pedagogical practices.

Table 4

Students Performances on Post-test (Higher level Cognitive domain)

\begin{tabular}{lccccc}
\hline \multicolumn{1}{c}{ Study Groups } & Mean & Std & $\begin{array}{c}\text { Mean } \\
\text { difference }\end{array}$ & $t$ value & $p$ \\
\hline $\begin{array}{l}\text { Experimental Group } \\
\text { Control Group }\end{array}$ & 40.14 & 5.291 & 2.200 & 3.347 & .000 \\
\hline
\end{tabular}

Table 4 reveals that the performances of students at higher level cognitive questions. The mean scores of experimental and control groups have significant difference. The mean score of experimental group was 40.14andthe mean score of control group was 37.94, the mean difference was 2.20 . The $t$ value 3.347 was significant at .000 . This shows that the 
students taught through authentic pedagogical practices performed higher than the other group of students.

Table 5

Students' retention in authentic and traditional pedagogical practices

\begin{tabular}{lccccc}
\hline \multicolumn{1}{c}{ Study Groups } & $\begin{array}{c}\text { Mean } \\
\text { S }\end{array}$ & Std & $\begin{array}{c}\text { Mean } \\
\text { difference }\end{array}$ & $\begin{array}{c}t \\
\text { value }\end{array}$ & $p$ \\
\hline $\begin{array}{l}\text { Experimental Group } \\
\text { Control Group }\end{array}$ & 35.26 & 5.954 & 9.30 & 10.116 & .000 \\
\hline
\end{tabular}

Table 5 explains the students' retention power in English taught through authentic and traditional pedagogical practices. The mean scores of experimental and control groups have significant differences. The mean score of experimental group was 35.26 and of the control group it was 25.96, the mean difference was 9.30. The $t$ value 10.116 was significant at .000 . These results provide evidence to the effectiveness of authentic pedagogical practices. Students' academic discussion, hands-on practices, knowledge construction and relating academic learning to societal norms enable the learners to retain the learning for a long span of time.

These results show that there was significant effect of authentic pedagogical practices on students' educational performances and there is significant difference between the students' retention power on authentic and traditional pedagogical practices.

\section{Discussion}

Classroom teaching practices emphasize on students learning. Teachers' adopts various approaches to enhance students' learning. All students centered approaches involves students actively in their learning process. Authentic pedagogical practices focus on student involvement in lower and higher order cognitive skills. As compared to traditional pedagogical practices, authentic pedagogical practices concentrate on the real life learning (Bartle, 2012).

Similarly, lower level cognitive learning is more effective in authentic pedagogical practices as compared to other traditional pedagogical practices (Maddox, 2014) and the reasons are hands-on practice, reflection on learning activities at classroom and such other opportunities in authentic pedagogical practices which has enhanced students' learning. Furthermore, students' performances in authentic 
instructions reflect their real abilities and are closely related to productive learning (Harm, 2013).

Students' classroom participation through discussion, class summary and group works are highly recommended by prominent research scholars (Baeten, Kyndt, Struyven, \& Dochy, 2010; Maddox, 2014) which are included in authentic pedagogical practices, they considered these practice are contributive in students' academic achievement.

Students learning through their practical involvement in learning process and hands-on practices concentrate on students' retention power. This study results are in accordance with that of Hussain, et al (2015) that students retain their learning for a long time if they are practically involve in it.

\section{Conclusion}

Students' educational performances are the ultimate target of all types of pedagogical practices. Results of the current study confirmed that authentic pedagogical practices are more effective for enhancing students' educational practices. These practices are helpful in enhancing students lower and higher level cognitive abilities. Authentic pedagogical practices provide opportunities for construction of knowledge, contextual definitions of words and connecting the classroom learning with social values which enables the students to enhance their educational performances.

Authentic pedagogical practices include all students of the class in the learning process. The learning activities are designed in such a manner that each students of the class give their input into the classroom learning. These practices enable the students to own their learning which contribute to boost students' educational performances. Students' higher retention power is the evidence of the effectiveness of authentic pedagogical practices. Practical involvement of students enables them to retain the learned skills and knowledge for a long time.

Furthermore, disciplined inquiry and problem solving skills are the other means for students' enhanced learning and high retention power which makes the students self-regulated learners. Students' engagement, practical experiences and relevance with real life situation is education beyond the classroom setting and is the basic components of authentic pedagogy. Students taught by authentic pedagogy have 
high level of retention power as compared to those taught by traditional methods.

The traditional pedagogical practices are not properly helping the students in enhancing their educational performances, while the authentic pedagogical practices have been proved effective for enhancing students' educational performances, it is therefore, recommended for secondary school teachers to adopt authentic pedagogical practices at secondary school level.

Rote memorization is subjected to low retention from students' perspective. The authentic pedagogical practices enable the students to work by themselves and construct knowledge carried out a discipline inquiry which ensure students' higher retention of learning materials. Therefore, authentic pedagogical practices are recommended for high retention of students' learning. Based on the results of the study as the authentic pedagogical practices were found effective the researcher also recommends the teacher education department, institutes, and colleges to include authentic pedagogical practices in the training of future teachers.

This study was conducted at secondary level in the subject of English. Future researcher may conduct the same study on higher education in some other subjects. It was conducted on male students at rural area, future research may also conduct the same study on female or both male and female students at urban or both urban and rural areas.

\section{REFERENCES}

Ahmad, N. (2011). A Comparative Study of the Nature of Difficulties and Factors Affecting the Learning of English by the Secondary School Students of Provincail and Federal Government Schools in Khyber Pakhtunkhwa. Islamabad: Foundation University Islamabad.

Baeten, M., Kyndt, E., Struyven, K., \& Dochy, F. (2010). Using student-centred learning environments to stimulate deep approaches to learning: Factors encouraging or discouraging their effectiveness. Educational Research Review, 244-247.

Bartle, C. (2012). Authentic Inquiry Pedagogy Implemented in Middle School Social Studies: Student and Teacher Perspectives. PhD Dissertation, University of Washington, College of Education. 
Dennis, J. J. (2005). Authentic Instruction: A Comparative Case Study Of Three Urdan High Schools. Ph. D Research thesis, University of Oklahoma, Graduate College, Department of Educational Leadership and Policy Studies.

Dennis, J., \& O’hair, M. J. (2010). Overcoming Obstacles in Using Authentic Instruction: A Comparative Case Study of High School Math \& Science Teachers. American Secondary Education, 2(10).

Gewirtz, S. (2009). Changing teacher professionalism : international trends, challenges, and ways forward. New York, NY: Milton Park, Abingdon, Oxon ; New York, NY : Routledge.

Given, C. (2013). A Nation Still at Risk: The Continuing Crisis of American Education and Its State Solution. Policy Paper. United States of America: American's for Prosperity Foundation .

Harm, J. E. (2013). Promoting Authentic Instruction Through Second-Career Educators. PhD Dissertation, Boise State University, Graduate College of Education.

Huang, S. (2014). Imposed or Emergent? A Critical Exploration of Authentic Pedagogy from Complex Perspective. Bristol, United Kingdom: University of Bristol, Graduate School of Education.

Hussain, S., \& Naz, B. A. (2013). The assessment of parent teacher councils in primary schools of district mardan. Hope Journal of Research, 1 (1), 122-139.

Hussain, S., Minaz, M., Ahmad, N., \& Idris, M. (2015). The Effects of E-Reading and printed Reading on students' Comprehension and Retention. 3rd International Conference on Computational and Social Sciences (ICCSS2015) (pp. 408-414-). Johor Bahru, Malaysia: AWKUM, UTM.

Hussain, S., Ahmad, N., Saeed, S., \& Khan, F. N. (2015). Effects of Flip Learning Approach on Prospective Teachers' Pedagogical Skills. The Dialogue A Quarterly Research Journal, 10 (3), 326-337.

Iacobucci, D., \& Adam, D. (2003). Advancing Alpha: Measuring Reliability With Confidence. Journal of Consumer Psychology, 13 (4), 478-487.

Maddox, L. E. (2014). Authentic Pedagogy and the Acquisition of Lower Order Knowledge in History. Social Studies Research and Practice, 9(1), 3-9.

Newmann, F. M. (2007). Authentic Instruction Assessment: Common strategies for rigor and relevance in teaching academic subjects. Research, Prepared for the Iowa Department of Education.

Newmann, F. M., \& Wehlage, G. G. (1993). Five Standards of Authentic Instruction. Educational Leadership, 50 (7), 8-12.

Newmann, F. M., Marks, H. M., \& Gamoran, A. (1995). Authentic Pedagogy: Standards That Boost Student Performance. Wisconsin Center for Education Research. Madison: Center on Organization and Restructuring of Schools. 
Watagodakumbura, C. (2013). Authentic Education: Visualising Education in a Deeper Perspective. World Journal of Education, 3(3), 2-9.

Received on: August 5, 2015 Revised on: December 11, 2015

Accepted on: December 17, 2015 